\title{
Sistem Informasi Pengajuan Pembuatan Kartu Kerluarga Berbasis Web Pada Kantor Catatan Sipil Kota Ternate
}

\author{
Darman Umagapi \\ Program Studi Manajemen Informatika \\ Politeknik Sains dan Teknologi Wiratama Maluku Utara \\ Umagapie01@yahoo.com
}

\begin{abstract}
Abstrak
Penilitian ini dilakukan untuk Pelayanan pembuatan Kartu keluarga berbasis website pada Kantor Catatan Sipil Kota Ternate. Tujuan penilitian ini adalah untuk merancang sistem informasi yang dapat memberikan kemudahan bagi penduduk dalam Pengajuan Membuat Kartu Keluarga pada Kantor Catatan Sipil Kota Ternate secara efisien. Jenis data penelitian adalah data sekunder yang diperoleh dari Kantor Catatan Sipil, melalui dokumentasi, metode analisis dan pengembangan sistem yang digunkan adalah metode Terstruktur, metode pendekatan Buttom-Up dan metode Prototype perancangan sistem informasi pengajuan pembuatan Kartu Keluarga berbasis web ini menggunakan bahasa pemograman HTML, PHP dan MySql sebagai Databasenya. Pengguna adaya sistem ini diharapkan mempermudah user dalam pengajuan pembuatan Kartu Keluarga.
\end{abstract}

Kata kunci : Sistem Informasi, Pengajuan, Kartu Keluarga, berbasis Website

\section{Abstract}

This research was conducted for website-based family card making service at ternate city civil registry office. The purpose of this study is to design an information system that can provide convenience for residents in the filing of making family cards at the civil registry office of ternate city efficiently. The type of research data is secondary data obtained from the office of civil registry, through documentation, method of analysis and system development used is structured method, button-up approach method and prototype method of designing information system of web-based card-making application using html programming language, php and mysql as its database. Users adaya this system is expected to facilitate the user in filing the family card.

Keywords: Information System, Submission, Family Card, Website

\section{PENDAHULUAN}

Seiring dengan kemajuan teknologi di berbagai bidang. Dari hari ke hari kemajuan teknologi terus berkembang, salah satunya adalah komputer. Komputer merupakan sarana untuk menyelesaikan pekerjaan dengan cepat, komputer bukan lagi barang yang aneh. Komputer begitu penting terutama sebagai penunjang segala kegiatan seperti belajar mengajar, kantor, bisnis dll. Dengan menggunakan komputer seseorang dapat memudahkannya dalam pekerjaan. manfaat dari komputer antara lain adalah :

1. Efisien waktu

2. Menghemat biaya

3. Menghemat tenaga

4. Kecermatan dalam menghitung

Peran yang diberikan teknologi informasi komunikasi ini adalah mendapatkan informasi dalam kehidupan sehari-hari, seperti informasi tentang Pengajuan pembuatan Kartu Keluarga, KTP, dan Akta Kelahiran. Bahkan kegiatan komunikasi yang dulu dianggap 
hal yang sulit sekarang diformulasikan dengan peralatan yang lebih canggih dan mudah dalam menggunakannya tanpa mengenal batas jarak dan waktu.

Orang bisa mengirimkan dan menerima berkas melalui email yang dikirim dari perangkat teknologi seperti komputer, laptop, netbook, PDA, atau Tab. Orang kini tidak perlu menghabiskan banyak waktu dan tenaga. Begitu juga dengan berbagai kebutuhan lain. Orang dapat memenuhi kebutuhan seperti berbelanja, membayar tagihan rekening listrik, tagihan telepon, mentransfer uang, dan seterusnya hanya melalui perangkat seperti laptop, telepon genggam, tablet, atau iPad.

Prosedur dan koordinasi kerja yang baik serta harus ditunjang oleh sumber daya manusia atau pegawai yang memiliki kemampuan kerja tinggi untuk melaksanakan hal tersebut, baik itu ketersediaan pegawai, peralatan kerja, komunikasi kerja, keterampilan pegawai dan pelayanan kerja dalam sebuah instansi tentu sangat membutuhkan pengelolaan sistem informasi. Tingkat produktifitas dan efektifitas kinerja suatu instansi salah satunya dapat dilihat dari pemanfaatan sistem informasi yang ada dinilai dari kecanggihan, keakuratan dan kepraktisan sistem yang diterapkan untuk pengolahan informasi.

Pelayanan pembuatan Kartu Keluarga adalah salah satu bentuk pelayanan publik yang dilakukan oleh pemerintah, Kartu Keluarga merupakan kartu identitas keluarga yang memuat data tentang nama, susunan dan hubungan dalam keluarga. Kegunaan dari Kartu Keluarga adalah menjadi bukti yang sah dan kuat atas status identitas keluarga dan anggota keluarga akan kedudukan keberadaan kependudukan seseorang menjadi dasar proses penerbitan Kartu Tanda Penduduk Kantor Catatan Sipil Kota Ternate.

\section{Rumusan Masalah}

Berdasarkan latar belakang tersebut, maka masalah dalam penelitian ini di rumuskan sebagai berikut: Bagaimana merancang Sistem Informasi Pengajuan Pembuatan Kartu Keluarga Berbasis Web di Kantor Catatan Sipil Kota Ternate?

\section{Tujuan Penilitian}

1. Untuk merancang aplikasi pembuatan Kartu Keluarga berbasiskan web pada Kantor Catatan Sipil Kota Ternate.

2. Membantu Admin dalam mengelola data pengajuan secara cepat

\section{Manfaat Penilitian}

1. Dapat meningkatkan kinerja dan pelayanan kepada masyarakat dalam melakukan pengajuan.

2. Mempermudah masyarakat melakukan pengajuan pembuatan kartu keluarga dimana saja.

\section{Tinjauan Pustaka}

Pada Penelitian yang dilakukan Akbar A Poipessy dan Mirna Umasagadji dengan Judul Pembuatan Aplikasi Jadwal Kerja Karyawan Pada SPBU Pertamina Kalumata Kota Ternate, dalam mengelola data karyawannya seperti absen dan jadwal karyawan masih dikelola menggunakan Aplikasi Microsoft Excel. Dimana datadata tersebut diinput dan dikelola pada setiap sheet, kekurangannya disaat admin ingin mencari data karyawan dan data jadwal atau ingin membuat laporan harus membuka dan memproses satu persatu pada sheet dan tidak secara otomatis dikelola pada satu sheet atau satu halaman saja, disisi lain data-data tersebut juga tidak tersimpan pada database sehingga 
suatu saat data tersebut bisa hilang dan terhapus, sehingga menganggap bahwa sistem pengelolaan data karyawan dan jadwal karyawan yang lama masih kurang efisien. Peniltian ini bertujuan untuk merancang Aplikasi Jadwal Kerja Karyawan Berbasis Website, diharapkan dapat membantu admin dalam mengelola dan mencari data karyawan, absen dan jadwal karyawan secara otomatis dalam satu halaman dan yang tersimpan pada database.

Penilitian yang dilakukan Ikwan Hi. Sambiu dan Yusdiana Amir yang berjudul Sistem Informasi Pesediaan Obat Pada Puskesmas Kalumata Berbasis Web, mengatakan bahwa pada puskesmas Kalumata sistem pengolahan untuk menangani data transaksi pembelian dan penjualan, mengontrol persediaan obat di gudang masih menggunakan aplikasi perkantoran yang umum digunakan yaitu Microsoft Office excel sehingga dianggap kurang efisien. Tujuan Penilitian ini untuk merancang satu sistem informasi persediaan obat yang lebih efektif dan efisien untuk dapat dipergunakan pada Puskesmas Kalumata Ternate, dengan adanya penelitian ini di harapkan dapat membantu apoteker dalam mengelola data transaksi dan stok obat secara efisien yang ada pada puskesmas kalumata ternate

\section{LANDASAN TEORI}

\section{Defenisi Sistem Informasi}

Berdasarkan pengertian sistem dan informasi, maka Sistem informasi merupakan suatu sistem yang mempunyai kemampuan untuk mengumpulkan informasi dari semua sumber dan menggunakan berbagai media untuk menampilkan informasi serta kumpulan dari bagian -bagian atau elemen-elemen yang saling berkaitan dan berhubungan untuk mencapai suatu tujuan yang telah ditetapkan sebelumnya untuk mencapai satu tujuan tertentu.

"Sistem informasi adalah sistem yang dapat didefinisikan dengan mengumpulkan, memperoses, menyimpan, menganalisis, menyebarkan informasi untuk tujuan tertentu. Seperti sistem lainnya, sebuah sistem informasi terdiri atas input (data, instruksi) dan output (laporan, kalkulasi)". Menurut Sutarman (2012),

\section{Karateristik Sistem}

Suatu sistem mempunyai karakterisktik atau sifat-sifat tertentu, yaitu mempunyai komponen-komponen (components), batasan sistem (boundary), lingkungan luar sistem (environments), penghubung (interface), masukan (input), keluaran (output), pengolah (process), dan sasaran (objectives). Menurut Jogiyanto (2013)

\section{Pengembangan Dan Pendekatan Analisis Sistem}

Proses pengembangan sistem seringkali menggunakan pendekatan prototype (prototyping). Metode ini sangat baik digunakan untuk menyelesaikan masalah kesalapahaman antara user dan analisis analisis yang timbul akibat user tidak mampu mengedentifikasi secara jelas kebutuhannya Muliyanto Agus (2012).

\section{Analisis Sistem}

Taufiq (2013), Analisis Sistem adalah suatu kegiatan mempelajari sistem (baik sistem manual ataupun sistem yang sudah komputerisasi) secara keseluruhan mulai dari menganalisa sistem, analisa masalah, desain logic dan memberikan keputusan dari hasil analisa tersebut. 


\section{Pendekatan Sistem}

Menurut Jerry Fitzgerald, Ardra F. Fitzgerald dan Warren D. Stallings, Jr.mendefinisikan prosedur pendekatan sistem sebagai berikut :Suatu prosedur adalah urutan-urutan yang tepat dari tahapan-tahapan instruksi yang menerangkan Apa (What) yang harus dikerjakan, Siapa (Who) yang mengerjakannya, Kapan (When) dikerjakan dan Bagaimana (How) mengerjakannya.

\section{Pengertian Kartu Keluarga}

Kartu Keluarga adalah Kartu Identitas Keluarga yang memuat data tentang susunan, hubungan dan jumlah anggota keluarga. Kartu Keluarga wajib dimiliki oleh setiap keluarga. Kartu ini berisi data lengkap tentang identitas Kepala Keluarga dan anggota keluarganya. Kartu keluarga dicetak rangkap 3 yang masing-masing dipegang oleh Kepala Keluarga, Ketua RT dan Kantor Kelurahan. Kartu Keluarga (KK) adalah Dokumen milik Pemda Provinsi setempat dan karena itu tidak boleh mencoret, mengubah, mengganti, menambah isi data yang tercantum dalam Kartu Keluarga.

\section{Pengertian Web browser}

Menurut Sibero (2013:11), "Website adalah suatu sistem yang berkaitan dengan dokumen digunakan sebagai media untuk menampilkan teks, gambar, multimedia dan lainnya pada jaringan internet". seperti Internet Explorer, google crome dan Mozilla Firefox dll.

\section{Pengertian Xampp}

Menurut Betha Sidik ( 2014), Xampp merupakan paket server web PHP dan database MySQL. Yang paling populer di kalangan pengembangan web menggunakan PHP dan MySQL sebagai databasenya.

\section{Pengertian MySQL}

Risnandar (2013) mengemukakan MySQL adalah basis data yang bersifat open source sehingga banyak digunakan didunia. MySQL juga mengenal beberapa tipe data antara lain :

1. Tipe Data Numerik

MySQL dapat menerima masukan berupa angka-angka yang dibagi atas integer (angka tanpa pecahan) dan floating-point (angka dengan pecahan).

2. Tipe Data Karakter

Merupakan deretan huruf yang membentuk kata yang diapit oleh tanda petik tunggal (") atau tanda petik dua ("')).

3. Tipe Data Waktu

Merupakan data yang berisi tanggal (date) dan jam (time).

\section{Pengertian PHP}

Menurut Sibero (2012), PHP (Personal Home Page) adalah pemograman (interpreter) adalah proses penerjemahan baris sumber menjadi kode mesin yang dimengerti komputer secara langsung pada saat baris kode dijalankan".

\section{Pengertian CSS}

Saputra dan Agustin (2012), Cascading Style Sheet atau sering disebut CSS merupakan suatu bahasa programan web yang digunakan untuk mengendalikan dan membangun berbagai komponen dalam web sehingga tampilan web akan lebih rapi, terstruktur dan seragam.

\section{Sistem Basis Data}

Ladjamudin (2013), database adalah sekumpulan data store (bisa dalam jumlah 
yang sangat besar) yang tersimpan dalam magnetic disk, oftical disk, magnetic drum, atau media penyimpanan sekunder lainya.

\section{Pengertian UML}

Menurut Arief Ikhwan (2011), UML (Unified Modeling Language) adalah sebuah bahasa untuk menetukan, visualisasi, kontruksi, dan mendokumentasikan artifact (bagian dari informasi yang digunakan atau dihasilkan dalam suatu proses pembuatan perangkat lunak. Artifact dapat berupa model, deskripsi atau perangkat lunak) dari system perangkat lunak, seperti pada pemodelan bisnis dan system non perangkat lunak lainnya.

\section{METODE PENELITIAN}

\section{Jenis dan Sumber Data}

Jenis data yang dilakukan oleh peneliti adalah data sekunder dimana data tersebut didapatkan dari hasil pengambilan dokumen. Sedangkan untuk sumber data sendiri peneliti khususkan tempat dimana peneliti jadikan objek penelitian yaitu pada Kantor Catatan Sipil Kota Ternate.

\section{Metode Pengumpulan Data}

Metode pengumpulan data yang digunakan dalam penelitian ini yaitu dengan mengambil dokumen dari staf administrasi pada Kantor Catatan Sipil Kota Ternate.

\section{Alat dan Bahan}

Software yang digunakan:

1. Sistem Operasional Windows7

2. Microsoft Office 2017

3. Microsoft Visio untuk membuat Flowchart atau UML

4. MySQL untuk database
5. PHP (Hypertext Preprocessor) untuk mengolah suatu data dan mengirimkannya kembali ke web browser menjadi kode HTML.

6. Xampp (sebagai server untuk mengeksekusi fungsi yang ada dalam halaman website yang telah di buat.

7. Notepad++ ( digunakan untuk membuat code editor (software penyunting kode.

8. HTML (HyperText Markup Language) untuk bahasa pemograman

Hardware yang digunakan :

1. Laptop Tosiba Intel Inside

2. Keyboard

3. Mouse Optik

4. Printer canon ip 2770

5. Ram 2 GB

6. HDD $320 \mathrm{~GB}$

\section{Analisa sistem yang berjalan}

Analisa sistem yang sedang berjalan pada Kantor Catatan Sipil Kota Ternate dapat dideskripsikan pada gambar sebagai berikut

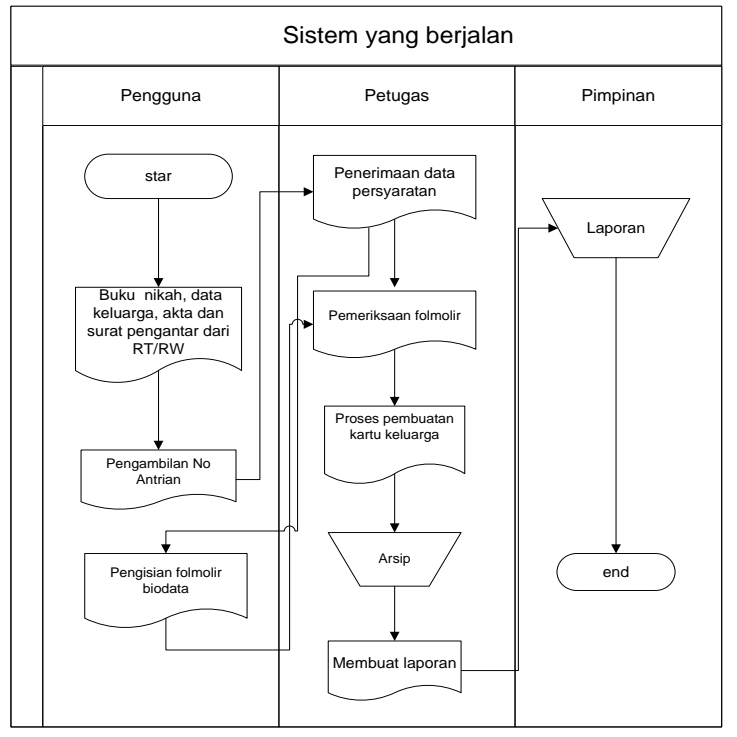

Gambar 1 : Sistem Yang Berjalan

Analisa System yang di usulkan 
Analisa sistem yang diusulkan dapat di deskripsikan pada gambar flowchart sebagai berikut::

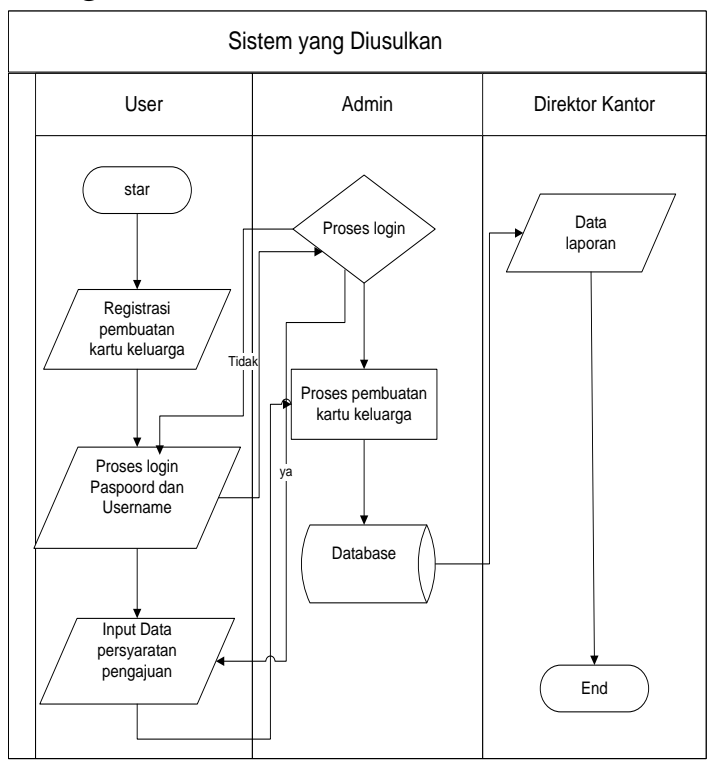

Gambar 2 : Sistem Yang diusulkan

\section{PERANCANGAN SISTEM}

Tahap perancangan sistem mempunyai dua tujuan utama yaitu memenuhi kebutuhan kepada pengguna dan untuk memberikan gambaran yang jelas dan rancangan yang lengkap. Hal-hal yang perlu didalam perancangan sistem meliputi Diagram Konteks, Data Flow Diagram (DFD), Entity Relationship Diagram (ERD), Referential Integrity, dan Rancang tampilan program.

\section{Diagram Konteks (ERD)}

Entity Relationship Diagram (ERD) atau Diagram antar Entitas adalah suatu diagram yang menggambarkan hubungan objek data yang disimpan yang ada dalam suatu sistem secara konseptual, dan dibuat secara agregasi.

Entity Relationship Diagram digunakan untuk menggambarkan hubungan yang terjadi di setiap entitas pada Sistem informasi pengajuan pembuatan kartu keluarga berbasis web pada Kantor Catatan Sipil Kota Ternate. Untuk lebih jelasnya dapat dilihat pada gambar berikut ini :

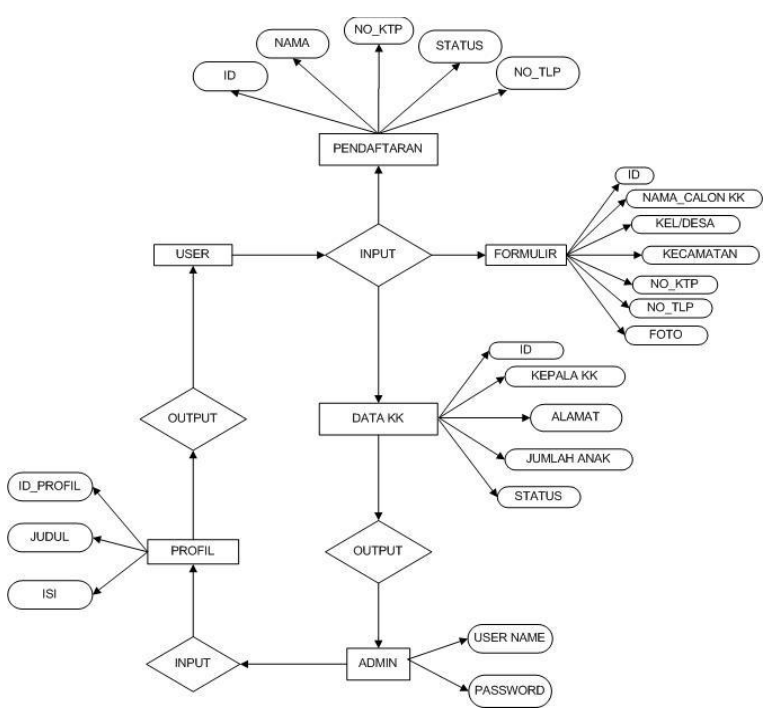

Gambar 3 : Diagram Konteks

\section{Relasi Tabel}

Relasi tabel merupakan suatu hubungan antar tabel yang saling berkaitan, pada sistem ini ada beberapa tabel yang saling berhubungan satu sama lain. Hubungan antar tabel ini dihubungkan dengan field kunci utama (primeri key) dan field kunci tamu (forign key), field kunci utama dalam tabel pada sistem ini yaitu field yang berada pada bagian pertama tabel dihubungkan dengan bagian yang selain dari baris pertama dalam tabel. Seperti yang digambarkan pada gambar berikut:

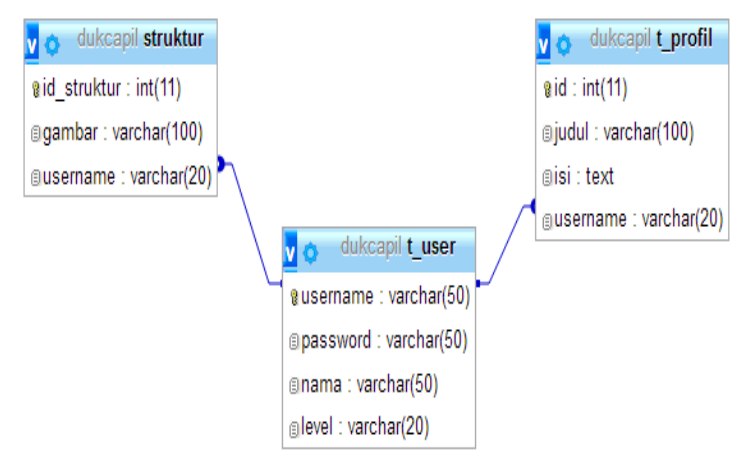

Gambar 4 : Relasi Antara Tabel 


\section{Perancangan Tabel}

\section{Tabel User}

Tabel Admin digunakan untuk menyimpan data - data yang berhubungan dengan user. Spesifikasi dari tabel Admin sebagai berikut :

Tabel 1: User

\begin{tabular}{|l|l|l|l|}
\hline Fieldname & Type & Size & Keterangan \\
\hline Username & Varchart & 50 & Username \\
\hline Password & Varchart & 50 & Pass user \\
\hline Nama & Varchart & 50 & User \\
\hline Level & Varchart & 20 & Level user \\
\hline
\end{tabular}

\section{Tabel Profil}

Tabel profil digunakan untuk menyimpan data yang berhubungan dengan profil. Spesifikasi dari tabel profil adalah sebagai berikut :

Tabel 2. Tabel Profil

\begin{tabular}{|l|l|l|l|}
\hline Field name & Type & Size & Keterangan \\
\hline Id & Int & 11 & Id profil \\
\hline Judul & Varchart & 100 & Judul profil \\
\hline Isi & Text & - & Isi profil \\
\hline
\end{tabular}

\section{Tabel Struktur}

Tabel struktur digunakan untuk menyimpan data yang berhubungan dengan struktur organisasi. Spesifikasi dari tabel struktur adalah sebagai berikut :

Tabel 3. Tabel Berita

\begin{tabular}{|l|l|c|l|}
\hline Field name & Type & Size & Keterangan \\
\hline Id & Int & 1 & Id berita \\
\hline Judul & Varchart & 100 & Judul berita \\
\hline Isi & Text & - & Isi berita \\
\hline Foto & Varchart & 100 & Foto berita \\
\hline
\end{tabular}

\section{Tabel Pengajuan}

Tabel pengajuan digunakan untuk menyimpan data yang berhubungan dengan data-data pengajuan pembuatan kartu keluarga. Spesifikasi dari tabel struktur adalah sebagai berikut :
Tabel 4. Tabel Pengajuan

\begin{tabular}{|c|c|c|c|}
\hline Fieldname & Type & Size & Keterangan \\
\hline $\begin{array}{l}\text { Id_pengaju } \\
\text { an }\end{array}$ & Int & 11 & Id pengajuan \\
\hline $\begin{array}{l}\text { Nama_leng } \\
\text { kap }\end{array}$ & Varchart & 50 & Judul berita \\
\hline Nik & Int & 20 & Nik pemohon \\
\hline Foto & Varchart & 100 & Foto berita \\
\hline $\mathrm{Jk}$ & Char & 1 & $\begin{array}{l}\text { Jenis Kelamin } \\
\text { pemohon }\end{array}$ \\
\hline $\begin{array}{l}\text { Tempat_lah } \\
\text { ir }\end{array}$ & Varchart & 100 & $\begin{array}{l}\text { Tempat lahir } \\
\text { pemohon }\end{array}$ \\
\hline Tgl_lahir & Date & - & $\begin{array}{l}\text { Tanggal lahir } \\
\text { pemohon }\end{array}$ \\
\hline $\begin{array}{l}\text { Alamat_len } \\
\text { gkap }\end{array}$ & Text & - & $\begin{array}{l}\text { Alamat } \\
\text { lengkap } \\
\text { pemohon }\end{array}$ \\
\hline Kode_pos & Varchart & 10 & $\begin{array}{l}\text { Kode pos } \\
\text { pemohon }\end{array}$ \\
\hline Telepon & Varchart & 20 & $\begin{array}{l}\text { No telepon } \\
\text { pemohon }\end{array}$ \\
\hline $\begin{array}{l}\text { Alasan_per } \\
\text { mohonan }\end{array}$ & Varchart & 50 & $\begin{array}{l}\text { Alasan } \\
\text { pemohon }\end{array}$ \\
\hline Jumlah_ & Int & 2 & $\begin{array}{l}\text { Jumlah } \\
\text { anggota } \\
\text { keluarga }\end{array}$ \\
\hline
\end{tabular}

\section{IMPLEMENTASI SISTEM}

\section{Halaman Depan Sistem (Home Page)}

Gambar di bawah ini adalah tampilan utama dari Perancangan sistem informasi pengajuan pembuatan kartu keluarga berbasis web pada kantor catatan sipil kota ternate. Tampilan ini berisi menu-menu utama yang di guanakan untuk menampilkan profil Kantor, dan data daftar baru pengajuan pembuatan kartu keluarga beserta informasi lainnya.

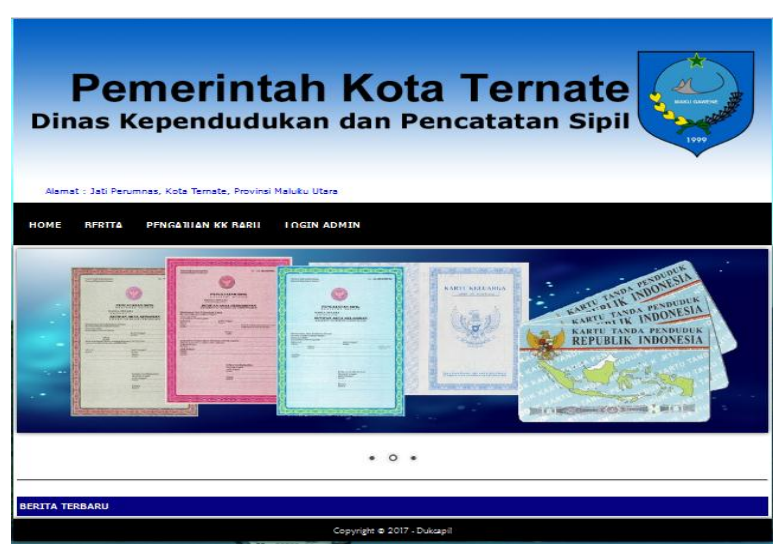

Gambar 5. Halaman Depan (Home Page) 


\section{Form Login Administrator}

Pada gambar di bawah merupakan halaman tampilan form login admin. Orang yang berhak melakukan akses pada halaman ini harus login terlebih dahulu dengan memasukan username dan password. Penguna yang berhak melakukan proses login ini adalah administrator.

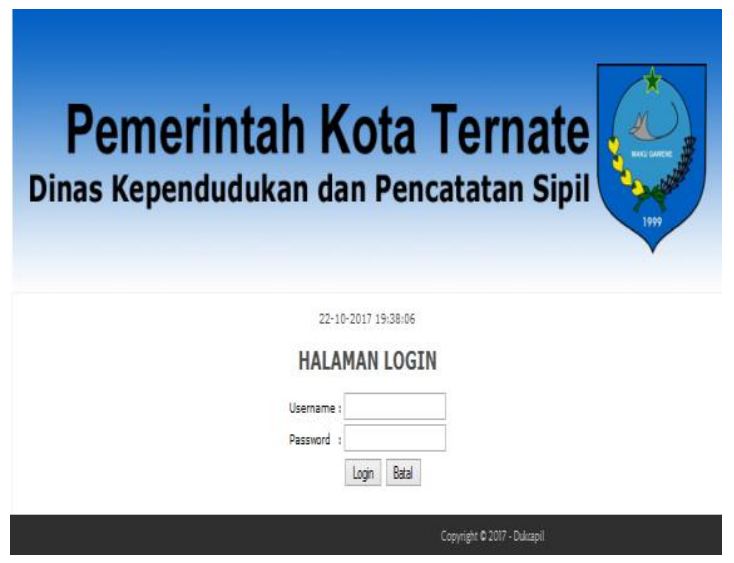

Gambar 6. Form Login Administrator

\section{Form Input Data Profil}

Pada gambar di bawah ini merupakan tampilan form untuk menginput data Profil Kantor Catatan Sipil Kota Ternate dan di simpan ke database yang nantinya di tampilkan di halaman data profil setelah mengclick tombol simpan. Tampilan dari halaman data profil adalah sebagai berikut:

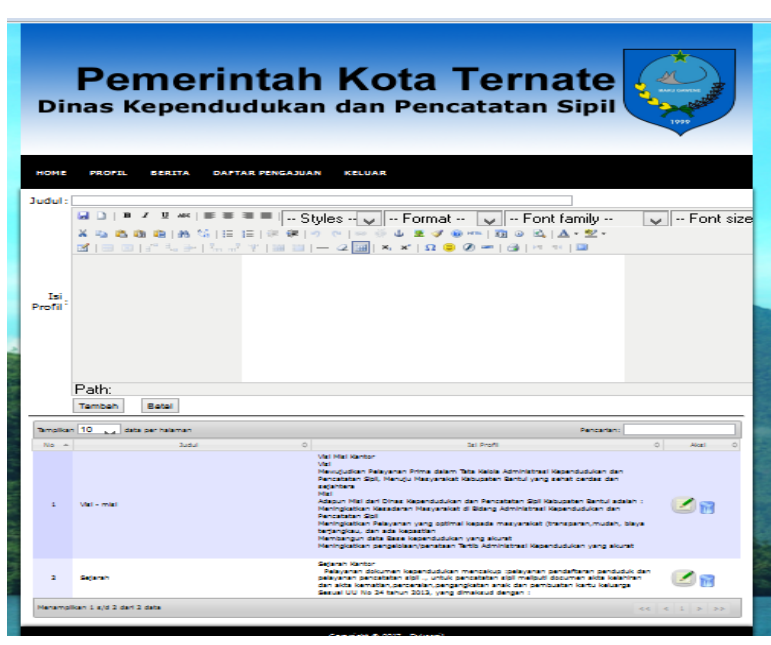

Gambar 7. Form Input data Profil

\section{Form Input Data Pengajuan KK baru}

Pada gambar di bawah ini merupakan tampilan form untuk menginput data Pengajuan Pembuatan KK Baru dan di simpan ke database yang nantinya di tampilkan di halaman data daftar Pengajuan Pembuatan KK Baru setelah mengclick tombol simpan.

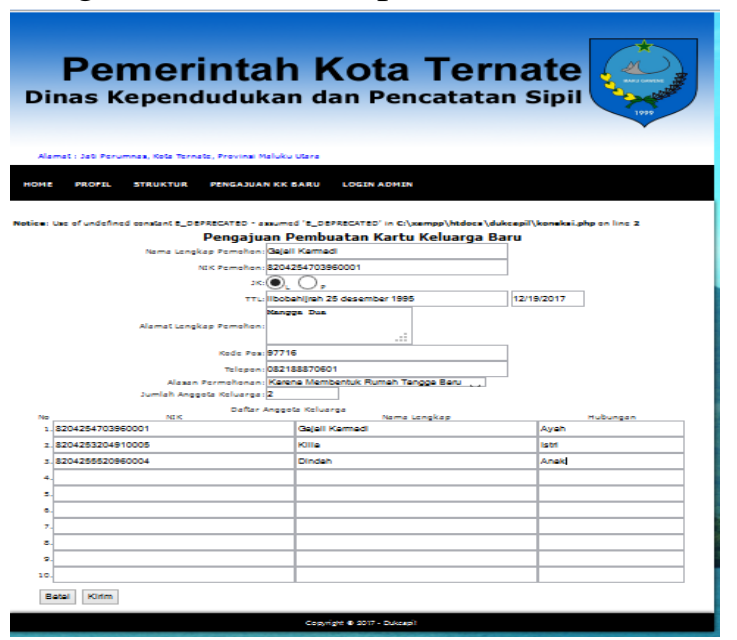

Gambar 8. Input data Pengajuan Pembuatan KK Baru

\section{Form Data Daftar Pembuatan KK Baru}

Pada gambar di bawah ini merupakan tampilan form data daftar Pengajuan Pembuatan KK Baru dan di simpan ke database yang nantinya di tampilkan di halaman data daftar Pengajuan Pembuatan KK Baru.

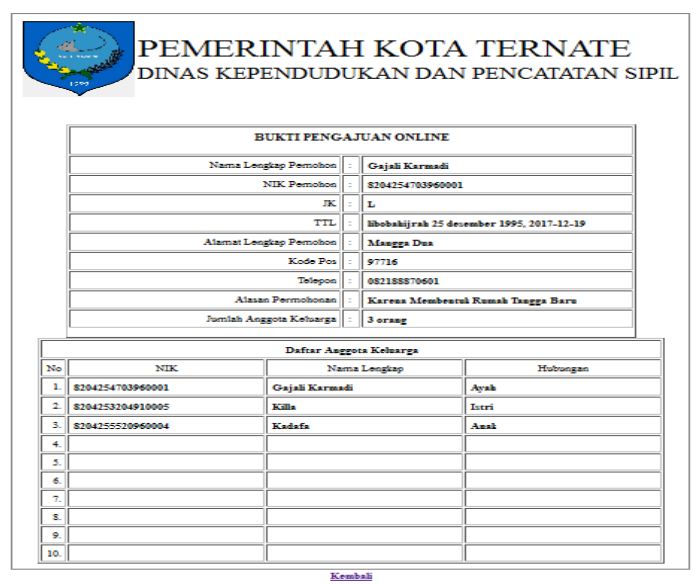

Gambar 9. Data Daftar Pengajuan

Pembuatan KK Baru 


\section{KESIMPULAN}

1. Prosedur pendataan dan pembuatan laporan pada sistem lama memiliki beberapa kelemahan yang menimbulkan masalah keamanan, tempat dan proses pembuatan Kartu Keluarga yang selama ini dilakukan secara manual sehingga memerlukan proses yang lambat dalam membuat laporan Pengajuan KK.

2. Sistem Baru yang dirancang terdiri dari form inputan data penduduk dan data kartu keluarga.

3. Sistem baru yang dirancang menghasilkan beberapa laporan antara lain data kepindahan penduduk, data penduduk, dan laporan data pemohon kartu keluarga.

\section{Saran}

1. Selain meningkatkan pelayanan terhadap warga, kepada Kelurahan Jati Kota Ternate, juga harus memperlihatkan kelebihan dan fasilitas dengan mengembangkan teknologi informasi komputer baik hardware dan software-nya.

2. Agar sistem komputerisasi ini dapat berjalan dengan baik maka diperlukan sumber daya manusia yang dapat menjalankan sistem dengan baik. 3). Sebaiknya data di-backup secara otomatis untuk menghindari apabila kehilangan data atau terkena virus.

\section{DAFTAR PUSTAKA}

Asropudin, P. (2013). Kamus Teknologi Informasi. Titian Ilmu. Bandung.

Al-Bahra, B. L. 2013. Analisis dan Desain Sistem Informasi. Graha Ilmu. Yogyakarta.

Buana, I Komang. S. 2014. Jago Pemrograman PHP. Penerbit Dunia Komputer. Yogyakarta
Fathansyah, 2012. Basis Data.. Informatika. Bandung

Hartono, B. 2013. Sistem Informasi Manajemen Berbasis Komputer. Rineka Cipta. Jakarta.

Indrajani, 2015 Database Systems Case Study All In One", 1thed,. PT. Jakarta

Kurniawan, B. 2012. Desain Web Praktis dengan CSS. Elex Media Komputindo. Jakarta.

Ladjamudin 2013, Rekayasa Perangkat Lunak, Graha Ilmu. Yogyakarta,

Mulyanto, Agus, 2012, Sistem Informasi Konsep \& Aplikasi, Pustaka Belajar, Yogyakarta.

Muharto \& Ambarita, A. 2016. Metode Penelitian Sistem Informasi:

Mengatasi Kesulitan Mahasiswa Dalam Menyusun Proposal Penelitian. Deepublish. Yogyakarta.

Supardi, Y. 2011. PHP dan MySQL. Ardikom Lautan Ilmu. Jakarta.

Saputra, A. 2011. Trik dan Solusi Jitu Pemrograman PHP. IKAPI. Jakarta

Sidik, B. 2012. Pemrograman Web dengan PHP. Santika Kencana. Solo

Sutarman, 2012. Pengantar Teknologi Informasi. Bumi Aksara. Jakarta.

Sibero, A. F.K. 2013. Web Programming Power Pack. Mediakom. Yogyakarta

Subhan, 2012. Analisan Perancangan Sistem. Lentera Ilmu Cendekia. Jakarta

Sutabri Tata, 2012. Analisis Sistem Informasi, Andi Offset. Yogyakarta

Taufiq R, 2013. Sistem Informasi Manajemen. Konsep Dasar, Analisis dan Metode Pengembangan. Graha Ilmu. Yogyakarta

Saputra, Agus. 2013. Membangun Aplikasi Toko Online dengan PHP dan SQL Server. PT Elex Media Komputindo. Jakarta

Widijanuarto, 2014. Jurus Kilat Membuat Jaringan Komputer. Dunia Komputer, Jakarta 